\title{
Effect of local estrogen application frequency on endometrial thickness in postmenopausal women
}

\author{
Sebastián Carranza-Lira, ${ }^{1 *}$ Yazmín del Carmen Culebro-Castro, ${ }^{2}$ Víctor Alberto Olguín-Cruces, ${ }^{3}$ \\ Sergio Rosales-Ortiz, ${ }^{4}$ Diana Sulvaran-Victoria ${ }^{5}$ and Elizabeth Sánchez-Merino ${ }^{3}$ \\ 'Division of Research in Health; ${ }^{2}$ Former Resident of the Obstetrics and Gynecology specialty; ${ }^{3}$ Anatomical Pathology Department; ${ }^{4} \mathrm{Ultrasound}$ \\ Department; ${ }^{5}$ Department of Endocrine Gynecology. Instituto Mexicano del Seguro Social, Hospital de Gineco-Obstetricia 4 "Luis Catelazo Ayala", \\ Ciudad de México, Mexico
}

\begin{abstract}
Introduction: Conjugated estrogens, when used by the vaginal route for the relief of vaginal dryness and atrophy, can produce endometrial changes. Objective: To know the effect of vaginal conjugated estrogens application frequency on endometrial thickness in postmenopausal women. Method: Seventy postmenopausal women with vaginal dryness who received conjugated estrogen cream $(0.625 \mathrm{mg} / 1 \mathrm{~g})$ for 12 weeks were studied. The women were divided according to application frequency as follows: group 1, twice-weekly $(n=35)$, and group 2, thrice-weekly $(n=35)$. At baseline and at end-of-treatment, vaginal cytology was examined to determine the estrogenic value, and an endovaginal ultrasound was performed to measure endometrial thickness. The comparison between groups was carried out with Mann Whitney's U-test, and the comparison between baseline and post-treatment values, with Wilcoxon's test. Results: Of 70 recruited women, only 38 were studied, 19 in each group, paired by baseline estrogenic value. No difference was found between groups, neither at baseline nor after treatment, in the maturation index, estrogenic value or endometrial thickness. Conclusion: There were no differences in endometrial thickness between the conjugated estrogen cream different application frequencies.
\end{abstract}

KEY WORDS: Endometrial thickness. Conjugated estrogens. Application frequency.

\section{Introduction}

Climacteric is the period that precedes and follows the cessation of menstruation. It involves biochemical and clinical alterations caused by the decrease of ovarian functions in the production of hormones and gametes. ${ }^{1}$ The vaginal epithelium is composed of several layers of cells, which are modified by estrogen deficiency. $^{2}$

It is possible to assess the degree of estrogenization of the vaginal epithelium by the maturation index, which is obtained from the percentage ratio of three types of vaginal cells (parabasal/intermediate/superficial) and with those, the estrogenic value is calculated. In early postmenopause, intermediate cells predominate and in the late phase, parabasal cells. ${ }^{3}$
Local estrogen therapy improves atrophy and vaginal dryness conditions by increasing the percentage of superficial cells. ${ }^{2,4}$

In the endometrium, the use of estrogens increases mitotic activity, which triggers proliferation. ${ }^{5,6}$ The postmenopausal endometrium, exposed to estrogen without opposition, must be closely monitored, which is possible with ultrasonographic measurement of its thickness. ${ }^{7-12}$ Different studies have compared transvaginal ultrasound with endometrial biopsy for the detection of endometrial pathology; they found that ultrasound has a negative predictive value of $99 \%$, sensitivity of $90 \%$, specificity of $48 \%$ and positive predictive value of $9 \%$ for the detection of abnormality; in addition, it is less painful and uncomfortable for the patient and more accessible. ${ }^{12-14}$
Correspondence:

*Sebastián Carranza-Lira

E-mail: drsebastiancarranza@ gmail.com
Date of reception: 24-09-2018

Date of acceptance: 24-01-2019

DOI: 10.24875/GMM.M19000255
Gac Med Mex. 2019;155:183-185

Contents available at PubMed www.gacetamedicademexico.com 
To avoid the risk of endometrial hyperplasia with the use of local estrogens by vaginal route, it seems prudent using them less frequently, e.g. only twice instead of thrice weekly.

The objective of the present study was to determine the effect of two different application frequencies of local conjugated estrogens on the endometrium of postmenopausal women.

\section{Method}

Prospective, longitudinal, comparative, controlled, open study in which postmenopausal women who were patients of an endocrine gynecology department were studied. All should have at least one year since menopause and refer vaginal atrophy and dryness. Women on hormone treatment or with any pathology that contraindicated the use of estrogens were not included. In all, age (years), weight (kg), height (m) and body mass index (BMI, weight in $\mathrm{kg} /$ height in $\mathrm{m}^{2}$ ) were documented, as well as waist and hip circumference (cm) were documented, and waist-hip index (waist circumference/hip circumference) was calculated.

In the women who agreed to participate, vaginal smear was obtained prior to treatment initiation, where the rate of maturation and estrogenic value were determined ${ }^{3}$ in addition, transvaginal ultrasound was performed, where endometrial thickness was measured. ${ }^{7}$ All cytological results were interpreted by the same physician, as well as ultrasonographic results.

All women received conjugated estrogens in the form of cream $(1 \mathrm{~g} / 0.625 \mathrm{mg})$ for three months and, according to the frequency of application, they were included in one of two groups:

- Group 1: twice weekly.

- Group 2: thrice weekly.

At the end of the treatment, a new vaginal smear was obtained and endometrial thickness was measured.

Considering a $95 \%$ confidence interval, a power of $90 \%$, a ratio of exposed-to-not exposed of 1 to 1 , an estimated frequency of change of $40 \%$ in the group with twice-weekly application and $80 \%$ in the thrice-weekly group, a sample size of 34 patients per group was obtained.

The comparison between groups was carried out with Mann-Whitney's U-test and the comparison between pre- and post-treatment values with Wilcoxon's test.

The protocol was authorized by the Local Research Committee and the Research Ethics Committee with registration number R-2016-3606-49.
Table 1. General data in two groups of postmenopausal women who received conjugated estrogens

\begin{tabular}{|l|c|c|}
\hline \multirow{2}{*}{ Variable } & Group 1 & Group 2 \\
\cline { 2 - 3 } & Mean (range) & Mean (range) \\
\hline Age (years) & $58(49-72)$ & $59(51-78)$ \\
\hline Weight (kg) & $70(50-97)$ & $60.5(50-104)$ \\
\hline Height $(m)$ & $1.57(1.42-1.64)$ & $1.49(1.45-1.68)$ \\
\hline Body mass index & $28.8(18.6-39.8$ & $27.1(21.8-48.0)$ \\
\hline Waist circumference $(\mathrm{cm})$ & $94(78-115)$ & $92(80-121)$ \\
\hline Hip circumference $(\mathrm{cm})$ & $100(89-118)$ & $99(94-115)$ \\
\hline Waist-hip index & $0.93(0.80-1.15)$ & $0.92(0.83-1.12)$ \\
\hline
\end{tabular}

Group 1: vaginal conjugated estrogen $0.625 \mathrm{mg}$ twice weekly.

Group 2: vaginal conjugated estrogen $0.625 \mathrm{mg}$ thrice weekly.

\section{Results}

Of the 70 women, 35 were in group 1 and $33 \mathrm{com}$ pleted the treatment; in group 2, of the 35 women, only 30 completed the treatment. When the groups were compared despite the fact that the women were included in each group alternately, differences were found between both in initial estrogenic value. For that reason they were paired by initial estrogenic value, with 38 women being finally left, 19 in each group ( $80 \%$ power); 17 and 16, respectively, in groups 1 and 2 , completed the treatment.

No difference was found between groups in age, weight, height, BMI, waist circumference, hip circumference and waist-hip index (Table 1).

When both groups were compared, there were no statistically significant differences in the percentage of parabasal, intermediate and superficial cells, or in maturation index, estrogenic value or endometrial thickness, neither before nor after treatment (Table 2).

When each group's baseline and final values were separately compared, in group 1 there was a significant decrease in the percentage of parabasal cells and an increase in estrogenic value after treatment. In addition, endometrial thickness was significantly increased.

In group 2, there was a significant decrease in the percentage of parabasal cells and an increase in intermediate and superficial cells. In addition, the estrogenic value did significantly increase. There was no significant change in endometrial thickness (Table 2).

\section{Discussion}

In this study, application both twice and thrice-weekly induced an increase in estrogenic value, which 
Table 2. Initial and final values in vaginal cytology parameters and endometrial thickness in two groups of postmenopausal women who received conjugated estrogens

\begin{tabular}{|c|c|c|c|}
\hline Moment & Parameter & Group 1 & Group 2 \\
\hline \multirow[t]{5}{*}{ Initial } & Parabasal (\%) & $100(0-100)^{a}$ & $100(0-100)^{A}$ \\
\hline & Intermediate (\%) & $0(0-100)^{b}$ & $0(0-100)^{\mathrm{B}}$ \\
\hline & Superficial (\%) & $0(0-5)^{c}$ & $0(0-5)^{c}$ \\
\hline & Estrogenic value & $0(0-52.5)^{d}$ & $0(0-52.5)^{\mathrm{D}}$ \\
\hline & $\begin{array}{l}\text { Endometrial } \\
\text { thickness (mm) }\end{array}$ & $2.2(1.4-3.1) e$ & $2.2(0.82-3.0)$ \\
\hline \multirow[t]{5}{*}{ Final } & Parabasal (\%) & $10(0-100)^{a}$ & $0(0-100)^{A}$ \\
\hline & Intermediate (\%) & $85(0-100)^{b}$ & $90(0-100)^{\mathrm{B}}$ \\
\hline & Superficial (\%) & $0(0-10)^{c}$ & $2.5(0-60)^{c}$ \\
\hline & Estrogenic value & $45(0-55)^{d}$ & $51.2(0-80)^{\mathrm{D}}$ \\
\hline & $\begin{array}{l}\text { Endometrial } \\
\text { thickness (mm) }\end{array}$ & $2.7(1.2-3.4)^{\mathrm{e}}$ & $2.4(0.8-3.6)$ \\
\hline \multicolumn{4}{|c|}{$\begin{array}{l}\text { Group 1: vaginal conjugated estrogen } 0.625 \mathrm{mg} \text { twice weekly. } \\
\text { Group 2: vaginal conjugated estrogen } 0.625 \mathrm{mg} \text { thrice weekly. } \\
\text { p-values: }\end{array}$} \\
\hline
\end{tabular}

indicates that both doses are sufficient to improve vaginal trophism. ${ }^{2,4,6}$

The endometrium proliferates with the application of estrogens, ${ }^{2}$ but, in the study, no differences were found between groups in terms of endometrial thickness, which indicates that they induce the same changes. In a review study, estrogen vaginal administration was reported to cause a non-significant increase in endometrial thickness; ${ }^{15}$ however, in the analysis of each group, only in the group with twice-weekly application was the increase found to be significant, with $22.7 \%$, while in the group with thrice-weekly application it was $9 \%$, which is an outcome we have no explanation for. It should be mentioned that thickness was within the "safety range". 5,11

Based on the above, it is possible to conclude that both application frequencies induce an improvement in the vaginal area without major endometrial involvement.

\section{References}

1. Carranza-Lira S. Introducción a la endocrinología ginecológica. México: Trillas; 2011.

2. Carranza-Lira S, Cabrera-López TJ, Estrada Moscoso I, Aguado-Pérez RA Índice de maduración y sequedad vaginales. Evaluación de dos dosis de estrógenos tópicos vía vaginal. Rev Med Inst Mex Seguro Soc. 2012;50:315-318.

3. Carranza-Lira S, Amador-Pérez C, MacGregor-Gooch AL. Índice de maduración y sequedad vaginales en la postmenopausia con uso de calcio y calcitriol. Rev Med Inst Mex Seguro Soc. 2012;50:537-540.

4. Suckling J, Lethaby A, Kennedy R. Local oestrogen for vaginal atrophy in postmenopausal women. Cochrane Database Syst Rev. 2006;4: CD001500.

5. Carranza-Lira S, Martínez-Chéquer JC, Santa-Rita MT, Ortiz de la-Peña A, Pérez Y, Fernández RL. Endometrial changes according to hormone replacement therapy schedule. Menopause. 1998;5:86-89.

6. Archer DF. Efficacy and tolerability of local estrogen therapy for urogenital atrophy. Menopause. 2010;17:194-203.

7. Carranza-Lira S, Ortíz-Rodríguez ML, Martínez-Chéquer JC, Santa Rita-Escamilla MT, García-Hernández E, Romo-Aguirre C. Correlación de los hallazgos histopatológicos con las variables ultrasonográficas del endometrio según el peso y distribución del tejido adiposo en la posmenopausia. Ginecol Obstet Mex. 1996;64:517-521.

8. Ozer A, Ozer S, Kanat-Pektas M. Correlation between transvaginal ultrasound measured endometrial thickness and histopathological findings in Turkish women with abnormal uterine bleeding. J Obstet Gynecol Res. 2016;42:573-578.

9. Van-Hanegem N, Breijer MC, Khan KS, Clark TJ, Burger MPM, Mol BWJ, et al. Diagnostic evaluation of the endometrium in postmenopausal bleeding: An evidence-based approach. Maturitas. 2011;68:155-164.

10. Sit AS, Modugno F, Hill LM, Martin J, Weissfeld JL. Transvaginal ultrasound measurement of endometrial thickness as a biomarker for estrogen exposure. Cancer Epidemiol Biomarkers Prev. 2004;13:1459-1465.

11. Sheng Q, Yang J Zhao Q, Li F. Dynamic monitoring of menopause hormone therapy and defining the cut-off value of endometrial thickness during uterine bleeding. J Biomed Res. 2016;30:191-196.

12. Omodei U, Ferrazzia E, Ruggeri C, Palai N, Fallo L, Dordoni D, et al. Endometrial thickness and histological abnormalities in women on hormonal replacement therapy: a transvaginal ultrasound/hysteroscopic study. Ultrasound Obstet Gynecol. 2000;15:317-320.

13. Saha TK, Amer SA, Biss J, Thakare H, Williams S, Farrell CT, et al. The validity of transvaginal ultrasound measurement of endometrial thickness: a comparison of ultrasound measurement with direct anatomical measurement. BJOG. 2004;111:1419-1424.

14. Sturdee DW, Panay N. Recommendations for the management of postmenopausal vaginal atrophy. Climacteric. 2010;13:509-522.

15. Lethaby $A$, Ayeleke RO, Roberts $H$. Local oestrogen for vaginal atrophy in postmenopausal women. Cochrane Database Syst Rev. 2016;8: CD001500. 